\title{
THE VALUE OF ALKALI IN SALICYLATE THERAPY
}

BY

\author{
NOAH MORRIS, M.D., and STANLEY GRAHAM, M.D.
}

(From the Department of Pædiatrics, University of Glasgow, and the Wards and Biochemical Laboratory, Royal Hospital for Sick Children, Glasgow.)

By virtue of their ability to control the arthritis of acute rheumatic fever, the salicylates have received a well-recognized place in the treatment of the rheumatic infection. Maclagan ${ }^{1}$ of Dindee in 1874 commenced the use of salicin, a glucoside of salicylic acid. To Stricker ${ }^{2}$, however, working in Traube's clinic in 1876, is given the credit of having first recognized the value of sodium salicylate. Broadbent ${ }^{3}$ in the same year also wrote enthusiastically in favour of its use, and it is interesting to note that even at this time the value of the larger doses was appreciated, Broadbent recommending $7 \frac{1}{2}$ to 20 grains hourly.

In 1908 Lees $^{4}$ spoke of the salicylates as specific in the cure of rheumatism, believing that the failure to obtain good results was due to the smallness of the dose. He also emphasized the necessity of giving alkali in addition and, while recognizing that the tolerance of the patient was greatly enhanced by this procedure, stated that the alkali was of benefit because it neutralized the toxins elaborated by the infecting agent and because the bicarbonate per se tended to lessen the degree of cardiac dilatation. This idea of salicylate being ' as specific to rheumatism as quinine is to malaria or mercury to syphilis' was not wholly accepted even at that time, and at present the general view of the value of the salicylates in rheumatism would appear to be that they are specific only for the arthritis but have no influence on the other manifestations such as carditis, chorea, etc.

Signs and symptoms of intolerance to salicylates are not infrequently observed, especially where the larger doses are given unaccompanied by alkali, and hence the use of alkali in equal or greater amounts than that of the salicylate employed has achieved a certain amount of popularity in the prevention of the toxic manifestations. In the writers' opinion, the value of the combination of salicylate and alkali would seem to have been definitely proved by routine clinical work. Nevertheless certain observers still deny the necessity of the use of alkali. In a comprehensive monograph on the salicylates written in 1924, Hanzlik ${ }^{5}$ categorically asserts that alkalis do not prevent or modify the appearance of toxic symptoms, and that the absence of toxic symptoms means absence of therapeutic efficiency. He quotes Meara ${ }^{6}$ as stating that the use of alkali ' is directed more by tradition than rationale,' but Meara was discussing the alkali treatment of rheumatism rather than the beneficial effect of the addition of alkali to sodium salicylate. 
At the Royal Hospital for Sick Children, Glasgow, it has been the custom to give sodium salicylate combined with twice the amount of sodium bicarbonate to every rheumatic patient during residence in hospital. The dosage of salicylate usually employed is 15 grains four-hourly, or 90 grains daily ; occasionally 20 grains four-hourly (120 grains daily) were given. With these doses signs of intolerance are seldom observed. Vomiting is the only one which may be said

TABLE 1.

SHOWING TOLERANCE OF CHILdREN TO SODIUM SALICYLATE Without SOdIUM BiCARBonate.

\begin{tabular}{|c|c|c|c|c|c|c|}
\hline Name & $\begin{array}{c}\text { Age } \\
\text { Years }\end{array}$ & $\begin{array}{l}\text { Daily dose of } \\
\text { Sod. Salicyl. } \\
\text { Grains }\end{array}$ & $\begin{array}{c}\text { Duration of } \\
\text { treatment. } \\
\text { Days }\end{array}$ & Vomiting & $\begin{array}{c}\text { Other signs } \\
\text { of } \\
\text { intolerance }\end{array}$ & Acetonuria \\
\hline B.G. & 7 & 50 & 40 & nil & nil & nil \\
\hline M.N. & 12 & 50 & 23 & nil & nil & nil \\
\hline F.K. & 10 & 60 & 35 & 1 & nil & nil \\
\hline I.J. & 12 & 60 & 14 & $9^{*}$ & nil & nil \\
\hline J.McL. & 9 & 60 & 48 & 1 & nil & $\begin{array}{l} \pm \text { When } \\
\text { vomiting } \\
\text { occurred. }\end{array}$ \\
\hline J.W. & 8 & 60 & 30 & 4 & nil & $\begin{array}{l} \pm \text { on } 2 \\
\text { occasions. }\end{array}$ \\
\hline K.C. & 9 & 60 & 16 & 5 & nil & $\begin{array}{l} \pm \text { occasion- } \\
\text { ally. }\end{array}$ \\
\hline A.S. & 6 & 90 & 3 & 3 & $\begin{array}{l}\text { Tremor, } \\
\text { nervousness, } \\
\text { acidosis. }\end{array}$ & \pm last day. \\
\hline J.S. & 7 & 90 & 4 & 2 & $\begin{array}{l}\text { Nervousness, } \\
\text { headache, } \\
\text { depression. }\end{array}$ & + last day. \\
\hline W.P. & 7 & 90 & 2 & 2 & $\begin{array}{l}\text { Tremor, } \\
\text { nervousness, } \\
\text { headache. }\end{array}$ & nil \\
\hline
\end{tabular}

*This patient vomited twice before commencement of sodium salicylate administration.

to occur with any frequency and if Langmead's? advice is remembered and the bowels kept freely open, it is rare that any intermission of the drug therapy is necessary. There are, of course, cases in which there does seem to be a special idiosyncrasy to salicylate just as occurs with many other drugs, e.g., arsenic and morphine. In these circumstances it is advisable to commence with smaller doses which can be gradually increased till the usual amounts are 
reached. Aspirin is thought by some to be tolerated better than salicylate of sodium, but actually the tolerance would appear to be related to dosage rather than to the particular form of salicylate used.

Clinical observations of the value of the added alkali.-A logical method of testing the value of the added sodium bicarbonate seemed to be to give certain patients salicylate alone and observe the ill-effects, if any, produced; then to add bicarbonate and note any diminution or alleviation of the toxic manifestations. It was soon found that 60 grains daily was the maximum amount which, without the addition of alkali, could be tolerated by the average child without toxic signs appearing. 50 grains daily in no case produced any ill effects, but 60 grains not infrequently produced slight vomiting which was not always attributable to constipation (Table 1).

If the daily amount was increased to 90 grains, signs of intolerance were invariably produced in 3 to 5 days, and in some cases these were of a severe and alarming nature. Vomiting was a constant and early sign and usually preceded all other manifestations of salicylism. Drowsiness and confused mental states or mental torpor occurred in some. Many became apathetic and disinterested, the speech in one instance was thick and slurring. Air-hunger of greater or less severity, but not necessarily in proportion to the other signs, occurred in all cases and sometimes to a marked degree ; this was the typical acyanotic dyspnœa which is known to be associated with an acidosis of the acid-poisoning type. Acetonuria was present in the majority of the cases, but was never extreme and in a few cases was entirely absent. Tinnitus, strangely enough, was not troublesome and in the present investigation was not complained of by any of the patients. This manifestation, however, has occasionally proved troublesome in some patients receiving both sodium salicylate and sodium bicarbonate in the routine way. All the above signs and symptoms disappeared rapidly on discontinuing the salicylate, or on the addition of twice the amount of bicarbonate.

It is an interesting and practical observation that in those cases to whom salicylate and bicarbonate had been previously given, the sig-as of poisoning on omitting the alkali either did not develop, or if they did were not as severe as in those to whom no alkali had previously been given. From Table 2 it will be seen that of the 9 patients to whom sodium salicylate and sodium bicarbonate had previously been given, 4 showed no toxic symptoms, in $\tilde{5}$ vomiting occurred and in only $l$ were there headache and depression. The last child, it is interesting to note, had only had the alkali combined with the salicylate for a short period of 7 days.

It seems indisputable, then, that whatever elsa the alkali may do, it is extraordinarily valuable in preventing the development of the signs and symptoms of salicylate poisoning. So striking is this that, in our opinion, it is unjustifiable to prescribe large doses of salicylate without giving in addition sodium bicarbonate.

The nature of the toxic manifestations.-There is considerable difference of opinion regarding the nature of the toxic manifestations caused by the salicylates. Certainly the clinical picture of a moderately severe case is that 
of a non-gascous acidos:s. There is definite air-hunger, the deep and frequent respirations being in some instances readily heard on entering the room. The beneficial effect of alkali would lend considerable support to this view, but so far no unequivocal evidence has been adduced to substantiate this. Hanzlik ${ }^{5}$ does not consider the reaction to be of the nature of an acidosis, but none of his objections are incompatible with such a disturbance. He draws a comparison between salicylate poisoning and the condition seen in diabetic acidosis

TABIE 2.

SHOWING BENEFICIAL INFLUENCE OF PREVIOUS ADMINISTRATION OF SODICM BICARBONATE ON TOLERANCE OF CHILDREN TO SODIUM SALICYLATE.

\begin{tabular}{|c|c|c|c|c|c|c|}
\hline Name & $\begin{array}{l}\text { Age: } \\
\text { Years }\end{array}$ & $\begin{array}{c}\text { Duration of } \\
\text { administration } \\
\text { of Sod. Sal. } \\
\text { gr. } 90+\text { Sod. } \\
\text { Bic. gr. } 180 . \\
\text { Days }\end{array}$ & Vomiting & $\begin{array}{c}\text { Duration of } \\
\text { administration } \\
\text { of Sod. Sal. } \\
\text { gr. } 90 . \\
\text { Days }\end{array}$ & Vomiting & $\begin{array}{c}\text { Other signs } \\
\text { of } \\
\text { intolerance }\end{array}$ \\
\hline A.McG. & 11 & 80 & nil & 28 & nil & nil \\
\hline J.W. & 9 & 78 & nil & 18 & nil & nil \\
\hline M.J. & 11 & 68 & nil & 33 & $\begin{array}{c}\text { Once on } \\
6 \text { th day. }\end{array}$ & nil \\
\hline M.F. & 9 & 67 & nil & 20 & nil & nil \\
\hline M.J. & 8 & 34 & nil & 11 & nil & nil \\
\hline R.McI. & 9 & 28 & nil & 12 & $\begin{array}{l}\text { Once on } \\
\text { 2nd day. }\end{array}$ & nil \\
\hline D.W. & 8 & 27 & nil & 15 & $\begin{array}{l}\text { Once on } \\
\text { 8th day. }\end{array}$ & nil \\
\hline R.S. & 8 & 24 & nil & 23 & Twice. & nil \\
\hline A.Mce & 11 & 7 & nil & 6 & $\begin{array}{l}\text { Twice on } \\
5 \text { th day. } \\
\text { Twice on } \\
6 \text { th day. }\end{array}$ & $\begin{array}{l}\text { Headache, } \\
\text { depression. }\end{array}$ \\
\hline
\end{tabular}

which he puts down to the action of certain enol acids. He finds air-hunger and acetonuria, but because there is no shift in the hydrogen ion-concentration, concludes that there is no acidosis.

The behaviour of the $\mathrm{CO}_{2}$ content of the blood.- The oral administration of sodium salicylate alone in doses amounting to 90 grains daily produced a marked fall in the $\mathrm{CO}_{2}$ content of the blood in every instance. The extent of this diminution is shown in Fig. 1. In all cases in which the blood was examined the fall was to a figure below 40 vol. per cent. With values between this and 
35 vol. per cent. symptoms such as vomiting and mild air-hunger began to appear. At 30 vol. per cent. symptoms were invariably present and frequently severe. On discontinuing the drug the blood fairly quickly returned to normal.

A fall in the $\mathrm{CO}_{2}$ content of this extent must mean either the development of a non-gaseous acidosis or a gaseous alkalosis. If the air-hunger be secondary, and we believe it is, then the condition must be a non-gaseous acidosis. Changes in the $\mathrm{pH}$ of the blood do not necessarily have to be demonstrated in order to diagnose a state of acidosis. The differentiation of compensated and uncompensated states depends on the sensitivity of the method of determining the $\mathrm{pH}$ more than anything else.

Changes observed in the urine.-It has long been known that albuminuria occasionally appears during salicylate administration. This naturally leads to the assumption that salicylates damage the renal cells. Hanzlik and his

FIGURE 1 .

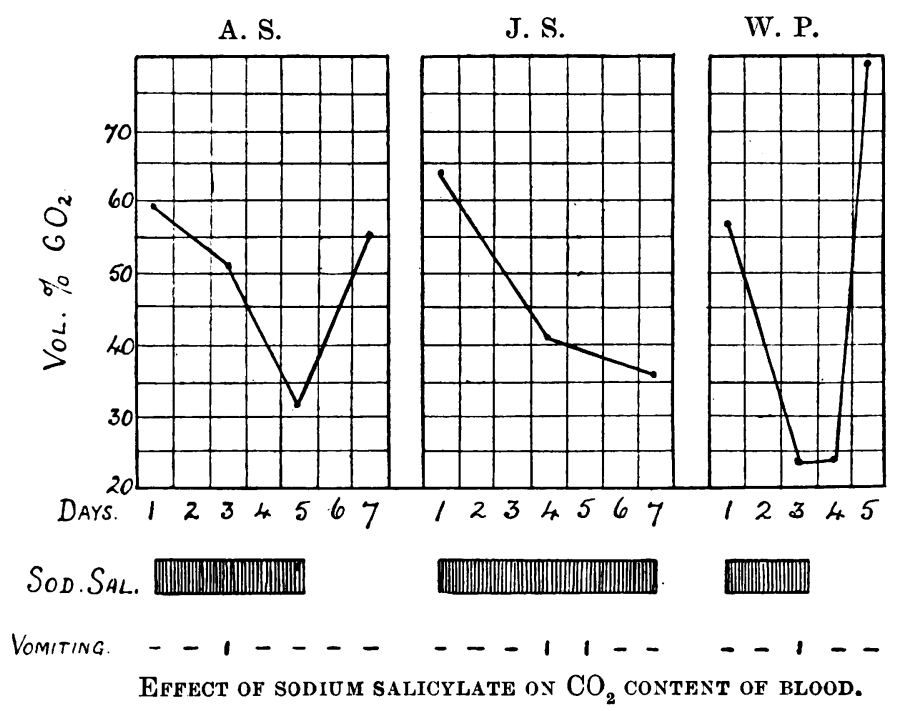

co-workers have published results which indicate a diminution in renal functional efficiency. We studied in three cases the changes which occurred in the urine as the result of salicylate administration with and without the addition of alkali.

The urine was collected from each patient for 3 periods of 6 days each. The first was a pre-period, during which time no drugs were given. During period II sodium salicylate (six doses daily of $15 \mathrm{grn}$. in one, and $10 \mathrm{grn}$. in the other two cases) was given; and during period III, the same amount of salicylate with twice the amount of sodium bicarbonate. During all three periods the diet, consisting of measured amounts of milk and sugar, was kept constant. In ro case was there any loss by vomiting. These results are tabulated in Table 3.

From our investigations many interesting facts emerge, the most striking being the fall in the ammonia coefficient of the urine during period II. As is 
well known a rise in this figure would be expected if the condition were an acidosis of the acid-poisoning type, and the fact that in each of the three cases there was a slight but distinct fall would appear to point to impaired renal function. It is of interest to mention here that one of us (N.M.) has recently had an opportunity of investigating a patient with cyclical vomiting during the course of an attack, and contrary to what was expected a distinct fall in the ammonia coefficient was observed at the height of the vomiting, although the $\mathrm{CO}_{2}$ content of the blood was very low. During period III, as expected, the fall was pronounced. Further investigation strengthens the suspicion of impaired renal efficiency. In two of the subjects there was roughly a 20 per cent. reduction in the volume of urine excreted during period II ; in the third

TABLE 3.

Changes observed IN THE URINe as a Result of administration of sodium salicylate WITH AND WITHOUT SODIUM BICARBONATE.

\begin{tabular}{|c|c|c|c|c|c|c|c|c|}
\hline Name & Period & $\begin{array}{l}\text { Volume } \\
\text { in c.cm. }\end{array}$ & $\begin{array}{l}\text { Titratable } \\
\text { acidity in } \\
\text { c.cm. } \mathrm{N} / 10\end{array}$ & $\begin{array}{l}\text { Ammonia } \\
\text { in grm. }\end{array}$ & $\begin{array}{c}\text { Total } \\
\text { Nitrogen. } \\
\text { grm. }\end{array}$ & $\frac{\mathrm{NH}_{3} \mathrm{~N} \times 100}{\text { Total N. }}$ & $\begin{array}{l}\text { Urea } \\
\text { grm. }\end{array}$ & $\begin{array}{l}\mathrm{NcCl} \\
\text { grm. }\end{array}$ \\
\hline B & $\begin{array}{l}\text { I } \\
\text { II } \\
\text { III }\end{array}$ & $\begin{array}{r}1,171 \\
954 \\
1,257\end{array}$ & $\begin{array}{r}167.2 \\
255 \cdot 3 \\
32.9\end{array}$ & $\begin{array}{l}0 \cdot 378 \\
0 \cdot 311 \\
0 \cdot 100\end{array}$ & $\begin{array}{l}9 \cdot 31 \\
8 \cdot 22 \\
8 \cdot 081\end{array}$ & $\begin{array}{l}4 \cdot 0 \\
3 \cdot 8 \\
1 \cdot 2\end{array}$ & $\begin{array}{l}18 \cdot 81 \\
13 \cdot 24 \\
15 \cdot 66\end{array}$ & $\begin{array}{l}2 \cdot 780 \\
1.906 \\
2 \cdot 425\end{array}$ \\
\hline M & $\begin{array}{l}\text { I } \\
\text { II } \\
\text { III }\end{array}$ & $\begin{array}{l}1,126 \\
1,125 \\
1,299\end{array}$ & $\begin{array}{r}155 \cdot 2 \\
222 \cdot 3 \\
34 \cdot 2\end{array}$ & $\begin{array}{l}0 \cdot 291 \\
0 \cdot 231 \\
0.062\end{array}$ & $\begin{array}{l}8 \cdot 49 \\
7 \cdot 68 \\
8 \cdot 18\end{array}$ & $\begin{array}{l}3 \cdot 4 \\
3 \cdot 0 \\
0 \cdot 77\end{array}$ & $\begin{array}{l}15 \cdot 85 \\
15 \cdot 43 \\
15.97\end{array}$ & $\begin{array}{l}2 \cdot 093 \\
1.545 \\
2 \cdot 398\end{array}$ \\
\hline $\mathrm{S}$ & $\begin{array}{l}\text { I } \\
\text { II } \\
\text { III }\end{array}$ & $\begin{array}{r}970 \\
721 \\
1,103\end{array}$ & $\begin{array}{r}132.5 \\
176.9 \\
11.7\end{array}$ & $\begin{array}{l}0 \cdot 344 \\
0 \cdot 189 \\
0 \cdot 052\end{array}$ & $\begin{array}{l}7.92 \\
7 \cdot 41 \\
8 \cdot 03\end{array}$ & $\begin{array}{l}4 \cdot 34 \\
2 \cdot 70 \\
0 \cdot 65\end{array}$ & $\begin{array}{l}15 \cdot 99 \\
13 \cdot 11 \\
16 \cdot 59\end{array}$ & $\begin{array}{l}1.727 \\
1.061 \\
1.776\end{array}$ \\
\hline
\end{tabular}

Period I $=$ No medication.

Period II = Sod. salicylate.

Period III $=$ Sod. salicylate + sod. bicarbonate.

case there was no change. It is worthy of note that in all three instances the addition of the alkali resulted in a marked increase of urinary volume. The urea output also was diminished in the sacond period and increased by the addition of the alkali. The total nitrogen of the urine was similarly affected, while evidence of chloride retention on salicylate alone is very definite. It may well be that the fall in $\mathrm{CO}_{2}$ of the blood and tissues is responsible for this retention of $\mathrm{Cl}$ in order to compensate for lost $\mathrm{CO}_{2}$, but the other obsarvations lend more support to diminished renal activity being the causal factor. The urea-concentration test $(15 \mathrm{grm}$. urea given) also gave corroborative evidence (Table 4). Here again the alkali restored the urea-concentrating power of the kidney to a normal level. Blood examination did not reveal any positive indication of kidney damage. The non-protein nitrogen and chlorine content were as far as we found always within normal limits. Hanzlik states that while the non-protein nitrogen of the blood is somewhat diminişhed the urea 
TABLE 4.

Showing efFect of administration of sodium Salicylate With and without Sodium bicarboNate on URea-concentrating powers of kil)ney. (Urea CONCENTRATION TEST).

\begin{tabular}{lllllll|l|l|l|l|l}
\hline Name & $\ldots$ & $\ldots$ & $\ldots$ & $\ldots$ & $\ldots$ & $\ldots$ & & B & & & \\
\hline
\end{tabular}

nitrogen is increased. He also maintains that the impairment of kidney function occurs equally with and without the use of alkalis. Our results with the ureaconcentration test (Table 4), as well as the improved urinary output of those patients receiving sodium bicarbonate as shown in Table 3, would appear to warrant the statement that sodium bicarbonate protects renal function. Albuminuria to us seemed of much more common occurrence when the patients were on salicylate alone.

Gastric secretion.-In view of the retention of chlorine resulting from administration of the salicylate alone, the effect on the gastric secretion of hydrochloric acid was studied. Leichentritt ${ }^{8}$ found that after the administration of sodium salicylate to dogs there occurred a definite increase in the volume of the gastric secretion. Veil and Graubner ${ }^{9}$, on the other hand, report cases in which one dose of a salicyl compound inhibited the formation of hydrochloric acid in the gastric juice. Our own results (Table 5) are inconclusive. It szems clear, however, that the secretion of acid is not necessarily prevented by salicylate, and that the diminished chlorine output in the urine cannot be explained by excessive secretion of gastric juice.

\section{TABLE 5.}

Showing efFect of adinistration of SODICM SALicylate With aNd Without SODIUM BICARBONATE ON THE GASTRIC SECRETION OF HCl FOLlowing Ewald TEST MEAL.

\begin{tabular}{|c|c|c|c|c|c|c|c|c|c|c|c|c|}
\hline Name & & $\ldots$ & $\ldots$ & $\ldots$ & $\ldots$ & $\ldots$ & \multicolumn{2}{|c|}{ M } & \multicolumn{2}{|c|}{$\mathrm{S}$} & \multicolumn{2}{|c|}{ M } \\
\hline Period & $\cdots$ & ... & $\cdots$ & $\ldots$ & $\ldots$ & .. & II & III & II & III & II & III \\
\hline \multicolumn{7}{|c|}{ c.cm. $\mathrm{N} / 10 \mathrm{HCl}$ in 100 c.cm. gastric juice } & 20 & 12 & 0 & 22 & 14 & 0 \\
\hline
\end{tabular}


Response to glucose and alkali.- It has been stated by Hanzlik $^{5}$ that the symptoms of salicyl poisoning resemble those occurring in diabetic acidosis. He quoted references to states of ketosis occurring in poisoning from methyl salicylate and mentioned the observation of Hurtley and Trevan ${ }^{10}$ on the similarity of the symptoms produced by intravenous administration of salicylate and sodium aceto-acetate. He brought forward the fact that salicyl gives a similar colour reaction with iron as does aceto-acetate as suggestive of the common cause of both types of intoxication.

It is true that occasionally acetone appears in the urine during administration of salicylate, but even in severe cases of poisoning it is by no means a constant constituent of the urine, and when present, it is rarely in greater amount than is indicated by a mild Rothera reaction. It may be urged that the impaired function is the cause of its non-appearance in quantity in the urine. The work of Myers and Ferguson ${ }^{11}$ indicates quite clearly that both

Figure 2. (A. B. \& C.)

A

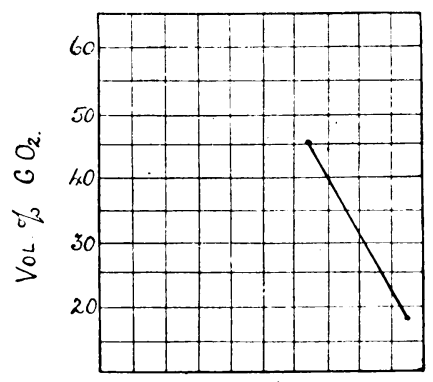

DAYS. 12345678910
B.

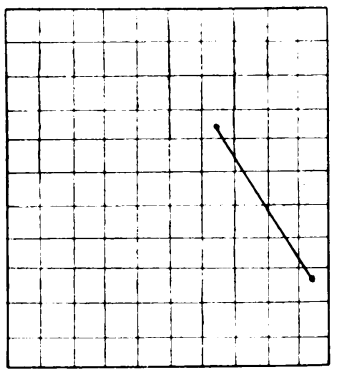

123456 y 8910

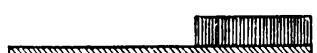

C.

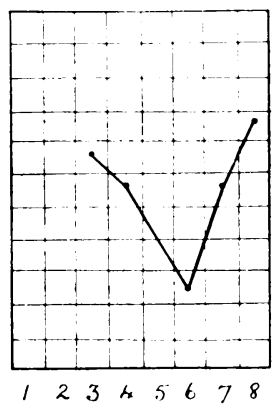

inm

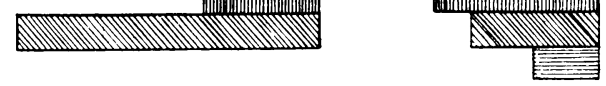

GLUCOSE.

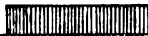

SOD. BIC.

Vomiting

AceTONURIA - - - - 12

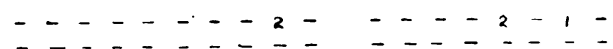

Effect of glucose and $\mathrm{NaHCO}_{3}$ in prefextion of Fall, in $\mathrm{CO}_{2}$ Content of blood.

in rabbits and man administration of sodium salicylate leads to little change in the percentage content of acetone bodies in the blood, although some of the rabbits received fatal doses of salicylate. The fact that acetone was said to play a part in the production of symptoms led us to investigate the effect of salicylate administration on the blood sugar as well as the influence of glucose ingestion in the prevention and amelioration of symptoms.

The fasting blood sugar was invariably higher during the period of salicylate ingestion, by about 15 per cent. It would seem, therefore, that there is available in the blood-stream a sufficiency of glucose. It is possible that owing to the action of salicylate the tissues are unable to make use of this glucose. This, however, is improbable and a much more likely explanation would appear to be a toxic action on the liver, by which that organ is rendered less capable of storing food material. This would explain not only the rise of fasting blood 
sugar but also the slight excretion of acetone bodies, since the liver also acts as a reservoir of fatty acids. It is also interesting in this connection to draw attention to the diminution in the formation of urea.

If there is any basis for the suggestion that ketone bodies play a part in the production of the symptoms of salicyl intoxication one would expect that the administration of glucose would have an inhibitory effect. In Fig. 2 is shown the effect of this on the blood $\mathrm{CO}_{2}$ content. Each patient was given 50 grammes of glucose daily for a period of about 6 days ; thereafter sodium salicylate was administered in $\mathbf{1 5}$ grain doses six times daily while the glucose was continued. In each instance symptoms developed and the total $\mathrm{CO}_{2}$ content of the blood fell just as quickly in those cases where no glucose or bicarbonate had been given previously or simultaneously. This chart also illustrates the variability of the acetonuria which was absent in two of the three cases. As the giving of glucose exerts not the slightest beneficial effect, it seems justifiable to infer that the symptoms are not necessarily associated with incomplete fat oxidation. In the mineral acid poisoning type of acidosis, such as one sees after the administration of $\mathrm{HCl}$ or acid-producing salts $\left(\mathrm{CaCl}_{2}\right.$ and $\left.\mathrm{NH}_{4} \mathrm{Cl}\right)$, glucose has no influence in preventing or lessening the symptoms. One is inclined to deduce from the results of these investigations a similarity between the nature of salicylate acidosis and that caused by such a substance as calcium chloride.

It has already been shown that the combination of sodium bicarbonate with the salicylate is effectual in lessening the impairment of renal function and in the great majority of patients preventing the onset of symptoms. Fig. 2 (C) shows that the addition of sodium bicarbonate in 30 grain ( 2 gramme) doses to salicylate on the sixth day resulted in a rapid return of the blood $\mathrm{CO}_{2}$ to normal and a disappearance of symptoms. This also is very similar to what occurs in the alkali treatment of $\mathrm{CaCl}_{2}$ over-dosage.

The excretion of salicylate.-In searching for the reason why the sodium bicarbonate is effectual in the prevention of the signs and symptoms of salicylate poisoning, the question of the rate of excretion of the drug with and without the addition of sodium bicarbonate naturally arises. The urine from periods II and III of the three children on metabolism was analysad quantitatively for salicylic acid. The fæces were also examined in one case but a negligible amount was found. These results are given in Table 6 . The giving of the alkali increased the excretion of salicylic acid by the urine two or four fold, and it seems impossible to avoid the conclusion that this increas 3 d rate of excretion is a potent factor in the beneficial effects of the alkali.

The amount of sodium salicylate in the blood of these three cases at the end of a night's fasting was estimated once during each period (Table 6). Free salicylic acid was never found except in traces, the drug always being present as the salt. The addition of the alkali also increased the salicylate content of the blood two to four times. The increase in the blood and the increased rate of excretion, however, do not necessarily go parallel. In the case of S. the blood salicylate content was increased seven fold in the third period, but the rate of excretion was only doubled. This observation, however, is not of great 
significance since the blood estimations were not done more than once and consequently the variations are not known, but it might be taken as suggesting that there are other factors, for example, kidney damage, as well as the 'head' of salicylate influencing the rate of excretion. Hanzlik's' ${ }^{12,13}$ findings are contrary to ours. He was unable to demonstrate any difference in the duration or rate of excretion by the addition of alkali. Fleischer ${ }^{14}$, however, stated that sodium bicarbonate shortens the period of elimination from 36 to 14 hours, and Ehrmann ${ }^{15}$ obtained similar results.

TABLE 6.

INFLUENCE OF SODIUM BICARBONATE ON THE URINARY EXCRETION AND BLOOD-CONTENT SODIUM SALICYLATE.

\begin{tabular}{|c|c|c|c|c|c|c|c|c|c|c|}
\hline \multirow{2}{*}{$\overline{\text { Name }}$} & \multirow{2}{*}{$\cdots$} & \multirow{2}{*}{$\cdots$} & \multirow{2}{*}{$\frac{\cdots}{\cdots}$} & \multirow{2}{*}{$\frac{\cdots}{\cdots}$} & \multicolumn{2}{|c|}{ B } & \multicolumn{2}{|c|}{$\mathrm{M}$} & \multicolumn{2}{|c|}{$\mathrm{S}$} \\
\hline & & & & & II & III & II & III & II & III \\
\hline \multicolumn{5}{|c|}{ Total amount of sod. sal. given in grm. } & $23 \cdot 33$ & $23 \cdot 33$ & $23 \cdot 33$ & $23 \cdot 33$ & 34.99 & 34.99 \\
\hline \multicolumn{5}{|c|}{ Total amount of sod. bic. given in grm. } & - & $46 \cdot 66$ & - & $46 \cdot 66$ & - & 69.98 \\
\hline \multicolumn{5}{|c|}{$\begin{array}{l}\text { Total amount of sod. sal. excreted in } \\
\begin{array}{rlllll}\text { grm. } & \ldots & \ldots & \ldots & \ldots & \ldots\end{array}\end{array}$} & 6.069 & $20 \cdot 25$ & $6 \cdot 57$ & $21 \cdot 33$ & $13 \cdot 17$ & 27.91 \\
\hline \multicolumn{3}{|c|}{$\%$ of sod. sal. excreted } & $\ldots$ & $\ldots$ & $26 \cdot 0$ & $86 \cdot 8$ & $28 \cdot 1$ & $91 \cdot 4$ & $37 \cdot 6$ & $80 \cdot 0$ \\
\hline \multicolumn{5}{|c|}{$\begin{array}{c}\text { Salicylate content of blood in mgrm. } \\
\text { per } 100 \mathrm{c.cm} .\end{array}$} & $9 \cdot 3$ & $29 \cdot 0$ & $6 \cdot 9$ & $13 \cdot 0$ & $13 \cdot 0$ & $94 \cdot 0$ \\
\hline
\end{tabular}

\section{Discussion.}

The question of the production of an acidosis in the poisoning by salicylate can, we believe, be answered in the affirmative. The clinical picture, the behaviour of the $\mathrm{CO}_{2}$ content, and the response to alkali, point very convincingly to this. The fact that renal function is impaired seems also quite definite and this is, in our opinion, the explanation of the reduced ammonia coefficient, since it is well recognized that the kidneys are the site of the formation of ammonia.

If there is an acidosis the question arises as to the nature of the excess acid. Although in this investigation the salicylate was always given as a neutral salt one naturally turns to the salicylic ion as a possible cause. The fact that this acid is present in the blood in greater abundance in the alkali period, in spite of the absence of symptoms, is itself strong evidence against it being the excess acid. Further, the amount found to be present during the low $\mathrm{CO}_{2}$ period is quite insufficient to compensate as a base-holding substance for the deficit in $\mathrm{CO}_{2}$. The maximum amount of salicylic acid which we found in the blood during the presence of toxic symptoms amounted to $13 \mathrm{mgrm}$. 
per cent., which is equivalent to 0.00094 mol. per litre. This amount would only account for a diminution in the $\mathrm{CO}_{2}$ of $2 \cdot 1$ vol. per cent., whereas the fall in $\mathrm{CO}_{2}$ amounted to more than $20 \mathrm{vol}$. per cent. It is clear therefore that the fall in $\mathrm{CO}_{2}$ is not merely the result of its replacement by salicylic acid.

The other alternative is the presence of an excess of acid produced as a result of disordered katabolism. Moderate increase of lactic acid has been observed in cats and rabbits after intravenous administration of salicylate preparations. Johnston ${ }^{16}$ who noted this could not correlate the lactate increase with the change in the alkaline reserve. There is strong evidence, however, of abnormal protein katabolism with the resultant production of acid nitrogenous substances. Unfortunately the partition of nitrogen in the urine was not studied, but it is clear from the figures presented that urea forms in two of the three subjects a much smaller proportion of the urinary nitrogen during the period when salicylate alone was given than in either of the other two periods. This cannot be explained by an increased formation of ammonia which was decreased in amount, absolutely as well as relatively. One possible explanation would be that owing to the action of the salicylic ion the process of de-aminization is inhibited, with a resultant increase of amino-acids in the blood. If to this is added the effects of impaired renal function, it might explain the excess acid accumulation leading to dyspnoa and a low $\mathrm{CO}_{2}$ content of the blood.

It is more than likely, too, that all the toxic symptoms and signs are not due to the presence of an acidosis. The delirium, speech disturbances, apathy and lassitude might quite well be the direct result of the salicylate itself or some of the compounds formed with it. Indeed, it seems more than probable that salicylate disturbs the metabolism of all the tissues just as has been demonstrated in the case of liver and kidney. Accordingly the nervous phenomena described can be more justifiably attributed to a direct action on nervous tissue than to the effects of acidosis. Both the acidosis and the manifestations of nervous involvement are concomitant phenomena, and it would appear that the extent to which the $\mathrm{CO}_{2}$ is lowered is a very good index of the degree of general disturbance of the tissues.

Whatever may be the immediate cause of the toxic symptoms it is beyond dispute that administration of alkali effectively prevents in the vast majority of individuals the onset of clinical symptoms or chemical changes of poisoning. The alkali undoubtedly accelerates the excretion of salicylate and so prevents its accumulation in the tissues. This would to a great extent explain its action in preventing signs of toxæmia. It would appear from the results shown that the functional activity of the kidney is restored to normal by the addition of sodium bicarbonate to the salicylate. Whether this is the sole action or not, one cannot say. It may in some way protect the tissues but conclusive evidence of this is lacking. At any rate the administration of sodium bicarbonate along with the salicylate is essential. Toxic manifestations are avoided and large doses of salicylate can be given with safety. Further, the alkali permits of a much greater concentration of salicylate in the blood, which presumably is of advantage in promoting the therapeutic effect. 


\section{Conclusions.}

1. The oral administration of sodium salicylate alone in doses of over 60 grains daily to children results in the production of a non-gaseous acidosis. The acidosis is not due to the presence of the acid salicyl ion per se.

2. In such patients there is also definite evidence of impaired renal function.

3. The development of the acidosis and the impairment of renal function can be prevented by the addition of sodium bicarbonate but not by glucose.

4. One effect of the alkali would appear to be the prevention of renal damage, thus permitting more rapid excretion of salicylate.

We desire to thank Dr. Leonard Findlay for his valuable suggestions and criticisms throughout the course of this investigation. We also tender our thanks to the Medical Research Council by whom the expenses of this work were defrayed.

\section{REFERENCES.}

1. Maclagan, T., Lancet, London, 1876, i, 349.

2. Stricker, Dr., Berlin Klin. Woch., Berlin, 1876, I, 15 \& 99.

3. Broadbent, W. H., Lancet, London, 1876, i, 530.

4. Lees, D. B., Proc. Roy. Soc. Med., London, 1908-9, II, (Pharmac. Sect.), 34 ; Brit. Med. J., London, 1912, ii, 930.

5. Hanzlik, P. J., Medicine, Baltimore, 1926, V, 197.

6. Meara, F. S., Amer. J. Med. Sci., Philad., 1910, CXXXIX, 328.

7. Langmead, F., Lancet, London, 1906, i, 1822.

8. Leichentritt, B., Ztschr. f. physiol. Chem., Berlin, 1919, CIV, 154.

9. Veil, W. H., \& Graubner, W., Arch.f. exp. Path. u. Pharmak., Leipzig, 1926, CXVII, 208.

10. Hurtley, W. H., \& Trevan, J. W., J. Physiol., Cambridge, 1915-16, Proc., 49.

11. Myers, H. B., \& Ferguson, C., J. Pharmac. \& Exper. Therap., Baltimore, 1929, XXXV, 313.

12. Hanzlik, P. J., Scott, R. W., \& Thorburn, T. W., Pharmac. \& Exper. Therap., Baltimore, 1917, IX, 247.

13. Hanzlik, P. J., Scott, R. W., \& Reycraft, J. L., Arch. Int. Med., Chicago, 1917, XX, 329.

14. Fleischer, R., Berl. Klin. Woch., Berlin, 1875, XII, 529 \& 547.

15. Ehrmann, R., Münch. Med. Woch., München, 1907, LIV, 2595.

16. Johnston, C. C., J. Am. Med. Ass., Chicago, 1930, XCIV, 784. 